\title{
ACADEMIC DISHONESTY 'VERSUS’ PAKTA INTEGRITAS \\ DAN PRESTISE SEKOLAH DALAM PELAKSANAAN UJIAN NASIONAL
}

\author{
Achmad Zaini \\ (Dosen PAI FTK UIN Sunan Ampel)
}

\begin{abstract}
:
This article tries to elaborate the academic dishonesty vis a vis integrity pact and school prestise during the implementation of Ujian Nasional (National Examination). It has been known that National Examination is still debatable. Many disagree to do it because the final evaluation must be returned to the teachers. Whereas, government agrees to do so in order to standardize the result of teaching learning process. To guarantee fair play in the exam, all headmasters sign integrity pact. Therefore, students are motivated to study hard to pass the exam. Unfortunately, many students even their teachers and headmasters cheat in many ways to achieve high results. The background can be traced into many factors: internal and external of the students and the prestige of the schools which "must be maintained" by national and private schools.
\end{abstract}

Keywords: Ujian Nasional, Academic Dishonesty, Pakta Integritas dan Prestise Sekolah 


\section{A. Pendahuluan}

Memasuki era globalisasi dan pasar bebas, bangsa Indonesia tidak hanya membutuhkan manusia dari segi kuantitasnya saja, namun yang lebih signifikan adalah menyangkut kualitas, baik menyangkut kualitas fisik: pengetahuan (knowledge) dan kemampuan (skill) yang dimiliki, juga menyangkut kualitas nir-fisik, yaitu hal-hal yang menyangkut kecerdasan emosi dan spiritual. ${ }^{1}$

Jenjang pendidikan menengah, khususnya sekolah menengah tingkat atas, dan pendidikan tinggi, merupakan tahapan yang sangat bermakna sebagai tempat pengembangan sumber daya manusia yang potensial sekaligus menyiapkan dan menghasilkan peserta didik yang berkualitas serta dilengkapi dengan keluhuran budi pekerti yang tinggi. Hal ini sesuai dengan tujuan pendidikan nasional yang bertujuan "untuk berkembangnya potensi anak didik agar menjadi manusia yang beriman dan bertakwa kepada Tuhan Yang Maha Esa, berakhlak mulia, sehat, berilmu, cakap, kreatif, mandiri dan menjadi warga negara yang demokratis serta bertanggung jawab."2

Menilik dari tujuan pendidikan nasional tersebut di atas dapat disimpulkan bahwa kualitas manusia Indonesia seutuhnya adalah manusia Indonesia yang memiliki ciri-ciri keserasian, keselarasan dan keseimbangan antara aspek jasmaniah dan ruhaniah. Namun, tujuan yang mulia tersebut terkadang menghadapi kendala yang cukup berat untuk mewujudkannya. Salah satu kendala yang berat adalah tidak adanya kejujuran dalam proses mencapai tujuan akademik atau yang lebih dikenal dengan istilah academic dishonesty dengan

1 Emil Salim, Mencari Strategi Pengembangan Pendidikan Nasional Menjelang Abad XXI (Jakarta: Grasindo, 1991), 30.

2 UU No. 20 Tahun 2003 tentang Sistem Pendidikan nasional. 
berbagai bentuknya termasuk menyontek yang sering dilakukan oleh peserta didik tidak hanya di level dasar juga di level pendidikan tinggi, yakni di kalangan peserta didik sekolah tingkat menengah dan mahasiswa bahkan dilakukan para dosen perguruan tinggi. Ironisnya, ketidakjujuran dengan segala macam bentuknya sering bahkan menjadi "budaya" di kalangan peserta didik, termasuk di kalangan peserta didik yang sedang melaksanakan ujian nasional.

Ketidakjujuran akademik dalam pelaksanaan ujian nasional di tingkat menengah atas (SMA) lebih mencuat dibandingkan di tingkat SMP atau bahkan SD dikarenakan adanya pro-kontra di kalangan birokrat pendidikan di level Kementerian Pendidikan Nasional dengan para akademisi di perguruan tinggi. Para birokrat pendidikan di level Kementerian Pendidikan Nasional ingin menjadikan hasil Ujian Nasional (UN) tidak hanya sekedar alat evaluasi keberhasilan peserta didik dalam menempuh jenjang pendidikan di SMTA, akan tetapi hasil UN dapat dipakai sebagai alat untuk masuk perguruan tinggi sekaligus, sehingga tidak perlu ada SNMPTN.

Di pihak lain, para akademisi perguruan tinggi memandang bahwa meskipun butir-butir soal yang ada pada UN sudah cukup baik, akan tetapi pelaksanaan UN penuh dengan ketidakjujuran untuk dapat dipakai standar masuk perguruan tinggi. Tulisan ini mencoba untuk mendeskripsikan hal-hal yang terkait dengan ketidakjujuran dalam pelaksanaan UN sehingga diketahui bagaimana pola-pola yang banyak dilakukan oleh para peserta didik bahkan pihak sekolah sekalipun dalam rangka menjaga prestise sekolah.

\section{B. Pengertian Academic Dishonesty}

Sebelum penulis mendefinisikan pengertian academic dishonesty terlebih dahulu penulis ingin mengilustrasikan 
kembali kasus penjiplakan skripsi (plagiarism) oleh Ipong S. Azhari untuk memperoleh gelar doktor (S3) di UGM. Masih terasa segar di ingatan, betapa kasus yang terjadi di Kampus Bulaksumur Jogjakarta tersebut telah mencoreng dunia akademik Indonesia. Terbongkarnya kasus Ipong S. Azhari diawali laporan Mochammad Nurhasim, peneliti pada Lembaga Ilmu Pengetahuan Indonesia (LIPI) ke Lembaga Senat UGM dan surat terbuka ke berbagai media massa.

Dalam suratnya tersebut, Mochammad Nurhasim menyatakan bahwa disertasi Ipong S. Azhari yang diterbitkan dengan Judul "Radikalisme Petani Masa Orde Baru: Kasus Sengketa Tanah Jenggawah pada pertengahan 1999" sama persis dengan skripsinya yang dipertahankan untuk memperoleh gelar sarjana (S1) di Universitas Airlangga. Setelah diadakan penelitian oleh tim, pada akhirnya Forum Senat Universitas Gadjah Mada (UGM) yang dihadiri 102 anggota senat pada tanggal 25 Maret 2000 membatalkan gelar doktor pada Ipong S. Azhari. Hal yang menarik, ternyata hampir semua data disertasi Ipong menggunakan data orang lain. Selain itu, data yang diserahkan saat ujian meraih gelar doktor tidak sama dengan disertasi yang dikumpulkan ke bagian arsip dan perpustakaan UGM. Disertasi yang diserahkan kepada penguji tidak menyebutkan sumbernya. Sementara, salinan disertasi yang diserahkan ke bagian arsip perpustakaan sudah mencantumkan sumber referensinya, yakni skripsi Mochammad Nurhasim. ${ }^{3}$

Kasus yang terjadi pada Ipong S. Azhari merupakan salah satu contoh dari kasus ketidakjujuran dalam dunia akademik. Kasus serupa sebagaimana kasus pada Ipong S.

3 Baca Hadi Nur, "Eika Sains; Aspek penting dalam Riset dan Pendidikan Tinggi di Indonesia," di Internet dengan alamat http://www.angelfire.com/mt/ hadinur/diskusi3.htm;Baca juga Majalah GAMMA No. 06-2-04-04-2000. 
Azhari sebenarnya banyak juga terjadi tidak hanya di Indonesia, tetapi juga terjadi di belahan dunia lainnya. Kasus terakhir yang menghebohkan dunia akademik Indonesia adalah pencurian ide yang dilakukan oleh salah seorang profesor dari Universitas Parahyangan. Profesor dalam bidang Hubungan Internasional yang masih muda dan cukup produktif tersebut akhirnya diproses terkait dengan academic dishonesty dan terancam dicabut gelar akademiknya.

Di level sekolah menengah bahkan di sekolah di level bawahnya sering juga terjadi kecurangan. Salah satu bentuk kecurangan yang dilakukan dan menjadi sorotan semua pihak adalah kecurangan dalam pelaksanaan ujian nasional. Pada tahun 2009, ada sebuah sekolah SMAN di daerah tapal kuda yang seluruh jawaban peserta didiknya sama, bahkan di salah satu sekolah di daerah Mataraman dengan terpaksa pelaksanaan UN diulang kembali karena sejak awal sampai akhir pelaksanaan ujian jawaban peserta didik sama semua, sama dalam arti jumlah yang benar dan yang salah sama serta nomor item soal yang benar dan yang salah sama juga.

Wujud ketidakjujuran akademik sering juga terjadi di kalangan peserta didik yang memperebutkan bangku di perguruan tinggi. Istilah "joki" sering muncul ketika SNMPTN dilaksanakan. Mereka akan menempuh jalan apapun asalkan mereka diterima di bangku kuliah yang menjadi idaman peserta didik SMA yang akan melanjutkan studi di tingkat lebih lanjut. Bahkan yang lebih tragis ketidakjujuran terjadi tidak hanya di kalangan peserta didik tetapi juga melibatkan guru dan pengawas sekolah di suatu daerah yang konon demi menjaga prestise daerah, mereka saling "bahu-membahu" melakukan ketidakjujuran dengan jalan memberikan kunci jawaban kepada peserta didik yang sedang mengikuti UN. 
Kasus yang terdeskripsikan di atas adalah salah satu bentuk ketidakjujuran dalam dunia akademik (academic dishonesty). Mereka yang telah melakukan penipuan saintifik, yakni usaha memanipulasi fakta-fakta atau menerbitkan hasil kerja orang lain secara sengaja dengan menyembunyikan sumber aslinya. Academic Dishonesty yang dilakukan oleh kebanyakan peserta didik sebagaimana paparan di atas dapat diartikan "to gain an unfair adventage by deception or breaking rules, especially in games and examinations," (untuk memperoleh keuntungan secara tidak fair dengan jalan menipu atau melanggar peraturan, terutama dalam permainan dan ujian). ${ }^{4}$

Bahkan definisi sebagaimana di atas mengalami perluasan makna menjadi "copying from books and assignments set in previous years, collusion amongst students in preparing assignments, getting assistance from relatives, using illegal notes and copying in tests in relaxed classroom setting" (menyalin dari buku dan tugas-tugas pada tahun sebelumnya, kolusi di antara peserta didik dalam menyiapkan tugas, mendapatkan bantuan dari teman atau keluarganya, menggunakan catatan ilegal dan menyontoh/menyalin jawaban pada waktu ujian dalam seting kelas yang longgar), 5 dan "using crib notes on an exam, copying answer from another student's paper, letting other copy a homework paper, plagiarizing and ghostwriting" (menggunakan catatan ilegal pada waktu ujian, menyalin jawaban dari teman

${ }^{4}$ Concise Oxford Dictionary, Thompson, 1995.

5 John R. Godfrey dan Russell F. Waugh, "The Perception of Student from Religious Schools about Academic Dishosnesty," dalam Issues in Educational Research, 8 (2), 1998: 95. Artikel bisa diakses melalui internet: http://education.curtin.edu.au/iier8/godfrey.html 
lainnya, mempersilahkan teman lainnya menyalin pekerjaan rumah, plagiat dan tulisan yang tersamarkan). ${ }^{6}$

Sedangkan menurut Kamus Umum Bahasa Indonesia karangan W.J.S Purwadarminta yang dipertegas lagi dalam Kamus Besar Bahasa Indonesia yang dikeluarkan Depdikbud definisi menyontek atau menjiplak atau ngerpek adalah mencontoh/meniru/mengutip tulisan, pekerjaan orang lain sebagaimana aslinya. ${ }^{7}$ Adapun menurut James S. Congelosi dalam bukunya Merancang Tes untuk menilai Prestasi Peserta didik, menyontek adalah "mengutip, mencontoh, meniru pekerjaan orang lain tanpa ijin; membuang sebagian halaman tes; mencuri soal ujian, hanya menghafalkan jawaban teman dari jenis tes yang sama di kelas lain; menyembunyikan lembar contekan; mengisi jawaban setelah lembar jawaban dikembalikan; meminta bantuan teman; menyembunyikan lembar contekan di kamar kecil; mencari kertas karbon bekas."8 Dari definisi yang disebutkan di atas jelas bahwa menyontek sebagai bagian dari academic dishonesty adalah setiap tindakan yang dilakukan oleh peserta didik secara tidak jujur dalam ujian maupun dalam mengerjakan tugas-tugas yang diberikan dalam mencapai hasil atau prestasi yang baik.

Ketidakjujuran akademik menjadi "common enemy" yang harus dilawan dan diberantas. Hal ini tentunya tidak lepas dari tujuan pendidikan yang ingin dikembangkan oleh semua institusi pendidikan, yakni peserta didik yang mempunyai integritas keilmuan yang jujur, disiplin, bertanggung jawab dan

${ }^{6}$ Bushway and Nash, 1977, 623 dalam John R. Godfrey and Russell F. Wough, "The Perception of Students from Religious Schools about Academic Dishonesty," Issues in Educational Research.

7 Departemen Pendidikan dan Kebudayaan, Kamus Bahasa Indonesia (Jakarta: Balai Pustaka, 1996), 403.

8 James S. Cogelasi, Merancang Tes untuk Menilai Prestasi Peserta didik (Bandung: ITB, 1995), 56-57. 
sportif dalam melaporkan proses pembelajaran dalam rangka mencapai tujuan yang telah ditetapkan oleh sebuah institusi.

\section{Faktor-faktor Penyebab Academic Dishonesty}

Faktor-faktor yang menyebabkan terjadinya ketidakjujuran saintifik atau akademik disinyalir oleh Hadi Nur dilandasi oleh tiga hal. Pertama, tekanan karir, dimana untuk melancarkan karir, seseorang terpaksa untuk melakukan penipuan. Tekanan ini dapat terlihat bagi para peserta didik program doktor di Jepang yang rata-rata harus mempunyai publikasi di jurnal dalam bidangnya untuk memperoleh gelar doktor. Atau adanya program sertifikasi bagi guru memaksa mereka untuk melakukan ketidakjujuran akademik dengan membeli sertifikat demi tercapainya kelulusan sertifikasi tersebut. Kedua, mengetahui atau berusaha menjawab pertanyaan dari riset tanpa susah payah melakukan eksperimen yang memakan waktu dan tenaga di laboratorium. Ketiga, diulang (reproducible). Hal ini dapat menjelaskan mengapa penipuan saintifik banyak terjadi pada bidang biologi dan biomedik, karena sulit mendapatkan data-data yang betulbetul bisa diulang, karena tergantung kepada banyak faktor yang susah dikontrol.

Tiga hal yang memotivasi seseorang untuk melakukan penipuan saintifik, nampaknya dilatarbelakangi oleh pengalaman Hadi Nur yang melanjutkan studi di Jepang dan bergelut dalam bidang eksakta yang lebih banyak menghabiskan waktunya di laboratorium. 
Menurut A. Hope MA, ${ }^{9}$ faktor-faktor yang dapat menyebabkan kebiasaan menyontek di kalangan peserta didik adalah sebagai berikut.

1. Faktor utama adalah tekanan yang terlalu besar yang diberikan kepada hasil studi yang berupa angka atau nilai yang dipelopori oleh tes, ulangan, ujian dan lain-lain. Anak yang mendapat angka tinggi mempunyai masa depan yang bisa lebih baik daripada anak lemah. Kemungkinan untuk masuk sekolah lanjutan lebih besar dan penghargaan dari orang tua dan guru terhadap anak yang berhasil dengan angka tinggi tentu mendorong anak untuk memperoleh nilai tersebut walaupun dengan cara-cara yang tidak dibenarkan, seperti menyontek, menyalin pekerjaan temannya, mengubah nilai pada kertas ulangan, dan sebagainya.

2. Pendidikan moril, baik di rumah maupun di dalam sekolah kurang diterapkan kedalam kehidupan anak-anak, sehingga kemampuan untuk membedakan antara tindakan yang benar dan tindakan yang salah kurang dikembangkan.

3. Kebiasaan menyontek lebih sering dilakukan oleh peserta didik yang kurang rajin belajar atau mereka yang menghadapi kesulitan belajar.

4. Anak remaja lebih sering menyontek daripada anak SD. Mungkin ini disebabkan karena bagi mereka populer di kalangan teman-temannya.

5. Ada peserta didik yang memandang menyontek sebagai kesempatan untuk melanggar peraturan sekolah atau untuk memberontak terhadap penguasa.

${ }^{9}$ A. Hope MA, Kebiasaan Nyontek adalah Musuh Perkembangan Anak (Jakarta: Rajawali, 1992), 87-89. 
Secara umum faktor-faktor yang menyebabkan peserta didik melakukan ketidakjujuran akademik (misal: menyontek) dapat diklasifikasikan menjadi dua, yaitu faktor eksternal dan faktor internal. ${ }^{10}$

\section{Faktor Eksternal}

Faktor eksternal yang menyebabkan terjadinya menyontek adalah faktor kesempatan. Dalam Pengantar Kriminologi dan Patologi Sosial ${ }^{11}$ dinyatakan bahwa adanya kecenderungan manusia untuk melakukan kejahatan apabila mereka dalam situasi kritis dan ada kesempatan untuk melakukannya. Ada beberapa teori yang menjelaskan kenapa manusia mempunyai kecenderungan untuk melakukan kejahatan, termasuk dalam dunia pendidikan yang wujudnya adalah academic dishonesty. "Closure Theory" yang dikemukakan oleh Prof. Edwin H. Lemert menjelaskan bahwa dalam usahanya mempelajari masalah-masalah pemalsu, nampak ada tipe naïve forgery. Mereka adalah orang-orang yang berada dalam situasi krisis. Situasi ini mereka pecahkan dengan membuat pemalsuan. ${ }^{12}$

Di samping faktor tersebut di atas, faktor lingkungan sekitar juga mempengaruhi seseorang untuk melakukan tindak kejahatan, begitu juga sebaliknya. Menurut Sosiologis kriminal, salah satu faktor yang memotivasi lahirnya kejahatan adalah lingkungan. ${ }^{13}$ Menurut Madzhab Lingkungan, kejahatan adalah gejala sosiologis, bukan gejala patologis. Orang berbuat jahat itu terjadi karena sifat

\footnotetext{
${ }^{10}$ Lihat Imam Haryanto, "Bahaya Menyontek di Kalangan Peserta didik," Pikiran Rakyat 18 Nopember 1985, hal. 7.

11 Lebih Lengkap baca B. Simandjuntak, Pengantar Kriminologi dan Patologi Sosial (Bandung: Tarsito, 1981)

${ }^{12}$ Simandjuntak, Pengantar Kriminologi ..., 240.

13 Simandjuntak, Pengantar Kriminologi..., 178.
} 
meniru. ${ }^{14}$ Madzhab ini menolak pandangan Lambroso, salah seorang pengikut madzhab Antropologi yang meyakini bahwa "manusia lahir telah ditakdirkan sebagai penjahat." Tesis yang dianut madzhab antropologi ini diruntuhkan dengan penelitian ilmiah yang melibatkan sampel penelitian sebanyak 100 orang penjahat dengan 100 orang yang bukan penjahat. Hasil penelitian ini meruntuhkan tesis Lambroso.

Wilbert J. McKeachie menyatakan bahwa "the pressure for good grades are so intense that many students feel that they, too, must cheat if they belive that other students are cheating ${ }^{15}$ (tekanan untuk mendapatkan nilai begitu intensnya menekan peserta didik sehingga banyak peserta didik merasa bahwa mereka juga harus menyontek jika mereka yakin bahwa peserta didik lainnya juga melakukan perbuatan menyontek)." Apa yang dikatakan McKeachie menunjukkan bahwa masih ditemukan kasus-kasus peserta didik yang tidak fair dalam memperoleh prestasi, khususnya nilai. Peserta didik yang berupaya jujur ternyata hanya dapat nilai cukup, sedang mereka yang menyontek dapat memperoleh nilai baik bahkan sangat bagus. Ketidakjujuran segelintir siwa pada akhirnya juga mempengaruhi peserta didik lainnya kecuali memperoleh prestasi yang sebaik-baiknya walupun dilakukan dengan jalan yang tidak fair.

Di samping faktor tersebut di atas, hal eksternal yang berkaitan langsung dengan faktor penyebab seorang peserta didik melakukan nyontek adalah tata ruang waktu ujian. Lokasi yang sempit dan jarak antar kursi yang begitu

\footnotetext{
95.

${ }^{14}$ Simandjuntak, Pengantar Kriminologi ..., 164.

15 Wilbert J. McKeachie, Teaching Tips (Lexington: DC Heath Company, 1994), 
dekat juga mempengaruhi seseorang untuk melakukan ketidakjujuran akademik melalui menyontek atau bertanya kepada teman di sebelahnya. Berdasarkan pengalamannya, McKeachie mengatakan bahwa "the most common form of cheating is copying from another student's paper. To reduce this, I usually ask to have a large enough exam room to enable students to sit in alternate seats. I write on the board befero students arrive." 16

\section{Faktor Internal}

Faktor internal yang mempengaruhi peserta didik untuk melakukan nyontek lebih bersifat psikolog (kejiwaan), antara lain dorongan kompetisi, perasaan takut, perasaan sedih dan sebagainya. Dorongan kompetisi merupakan salah satu dari dorongan-dorongan psikis yang dipelajari seseorang dari kebudayaan dimana ia hidup. Pendidikan dan pengalaman yang diterima seseorang akan mengantarkannya pada aspek-aspek dimana kompetisi dipandang baik demi kemajuan dan perkembangannya dan sesuai dengan nilai-nilai yang dipegangi oleh masyarakat dimana seseorang itu hidup.

Al-Qur'an sendiri memberikan dorongan pada manusia untuk berkompetisi dalam bertaqwa kepada Allah SWT, berbuat kebajikan, berpegang teguh pada nilai-nilai manusiawi yang luhur, dan mengikuti metode ilahi dalam kehidupan, baik dalam hubungan mereka dengan Allah SWT, dalam hubungan kekeluargaan atau dalam hubungan mereka dengan masyarakat, agar mereka bisa mendapatkan karunia dari Allah SWT. Banyak sekali ayat Al-Qur'an yang menyarankan kepada manusia untuk selalu berkompetisi dalam semua hal kebajikan, seperti QS al-

16 Wilbert J. McKeachie, Teaching Tips, 97. 
Maidah: 48 yang artinya :"Maka berlomba-lombalah berbuat kebajikan. Hanya kepada Allah-lah kamu semuanya kembali, lalu diberitahukan-Nya kepadamu apa yang telah kamu perselisihkan itu."

Dalam QS al-Baqarah: 148, Allah SWT berfirman: "Dan bagi tiap-tiap orang ada tujuan (sendiri) yang diarahnya. Maka berlomba-lombalah kamu (dalam berbuat) kebaikan..." Namun, dorongan untuk berkompetisi yang seharusnya dimiliki oleh peserta didik untuk hal-hal yang baik, malah disalahgunakan untuk mencapai hasil baik tanpa harus bekerja keras. Peserta didik yang seharusnya banyak menggunakan waktunya untuk belajar, Kenyataannya sebaliknya. Demikian juga dengan faktor psikis lainnya, misalnya, perasaan takut tidak lulus, nilainya jelek, ingin dipuji dan sebagainya juga mempengaruhi seseorang untuk melakukan hal-hal yang tidak baik.

Seharusnya perasaan-perasaan psikis tersebut disikapi secara positif. Seorang peserta didik atau peserta didik yang ingin mendapatkan prestasi yang baik maka dia harus melakukan sebuah proses yang panjang. Dia harus banyak meluangkan waktu ke perpustakaan, banyak membaca, berdiskusi dan sebagainya dalam rangka mendapatkan prestasi yang baik. Bukan sebaliknya, seorang peserta didik inginnya santai melulu, waktu yang digunakan untuk belajar sangat minim dibanding dengan kegiatan lainnya, tapi ingin mendapat prestasi yang baik. Maka, tidak ada jalan lain bagi peserta didik tipe kedua tersebut kecuali melakukan hal-hal yang tidak fair.

Pada dasarnya pergumulan aspek kejiwaan mendorong peserta didik untuk melakukan apa saja agar hasrat dan keinginan untuk mencapai yang terbaik dapat diraih walau jalan yang ditempuh keliru atau keluar dari 
rel-rel yang sudah ditentukan. Kedua faktor tersebut saling berpengaruh terhadap diri peserta didik dalam melakukan kegiatan academic dishonesty (menyontek).

\section{Pakta Integritas vis a avis Academic Dishonesty dan Prestise Sekolah}

Pelaksanaan ujian nasional di level sekolah menengah atas menjadi perhatian yang luar biasa karena diharapkan ujian nasional dapat berjalan dengan fair dan sejujur-jujurnya. Untuk mengantisipasi ketidakjujuran tersebut, Kementerian Pendidikan Nasional dan BNSP sepakat melibatkan perguruan tinggi untuk mengawasi pelaksanaan UN. Di samping itu, semua pelaksana UN menandatangani pakta integritas yang menyatakan akan melaksanakan UN dengan sejujur-jurunya.

Meski ada pakta integritas, namun disinyalir bahwa pelaksanaan UN masih mengalami ketidakjujuran. Ketidakjujuran pelaksanaan UN setidaknya, sebagaimana penjelasan di atas, dipengaruhi oleh dua faktor, yaitu eksternal dan internal. Faktor eksternal, ada target daerah (provinsi) yang mematok bahwa tingkat kelulusan peserta didik sebuah provinsi harus mencapai porsentase tertentu. Hal ini biasanya dipahami oleh kepala dinas sebagai sebuah perintah atasan yang harus "diamankan" sebagai sebuah kebijakan. Kepala dinas kemudian menginstruksikan para kepala sekolah termasuk para pengawas untuk ikut mengamankan kebijakan tersebut sehingga target pimpinan tercapai. Apabila target pimpinan tidak tercapai maka konsekwensinya adalah "dicopot" dari jabatan baik sebagai kepala dinas ataupun kepala sekolah.

Hal inilah yang menjadi pemicu pihak sekolah (khususnya sekolah negeri) untuk melakukan ketidakjujuran dalam pelaksanaan UN. Bagi para kepala sekolah swasta atau yayasan, tingkat kelulusan siswa pada UN merupakan sebuah 
taruhan eksistensi yayasan atau sekolah pada tahun berikutnya. Apabila sekolah tersebut dapat meluluskan peserta didiknya 100\%, maka sekolah tersebut akan diminati oleh masyarakat. Sebaliknya, semakin tinggi tingkat ketidaklulusannya maka sekolah tersebut akan ditinggalkan masyarakat dan akhirnya tutup. Di samping dua hal tersebut di atas, ada yang sengaja melakukan academic dishonesty karena dia memang tidak setuju dengan adanya UN. Sampai kapanpun UN dilaksanakan, dia akan tetap melakukan ketidakjujuran dalam pelaksanaannya.

Di samping faktor eksternal, faktor internal peserta didik juga mempengaruhi ketidakjujuran dalam pelaksanaan UN. Ketidaksiapan peserta didik disebabkan antara lain mengharapkan dapat jawaban dari gurunya atau temannya berdasarkan pengalaman tahun sebelumnya sehingga mereka malas untuk belajar.

Pola-pola yang digunakan dalam melaksanakan ketidakjujuran UNAS dapat diklasifikasikan dalam 2 hal saja, yaitu:

1. Sekolah membentuk tim sukses

Tim sukses yang dibentuk oleh sekolah ini dapat dibagi dalam 2 kelompok dalam menjalankan modus operandinya, yaitu:

a) Memberikan jawaban kepada siswa secara langsung Sekolah biasanya membentuk tim guru yang mata pelajarannya di-UN-kan. Hal ini dimungkinkan karena jeda waktu pengambilan naskah di polsek dengan pelaksanaan UN relatif cukup lama (kurang lebih 3 jam) dan biasanya tidak ada pengawalan baik dari pihak kepolisian maupun dari tim independen. Tidak adanya pengawasan dari kepolisian dikarenakan jumlah personil dari kepolisian tidak mencukupi untuk mendampingi setiap sekolah yang mengambil soal ujian 
nasional. Tim independen yang dibentuk oleh perguruan tinggi dan BNSP juga tidak sampai menyentuh pada pengawasan pengambilan soal dari polsek sampai sekolah.

Waktu itu jeda yang cukup lama tersebut dapat "dimanfaatkan" oleh para oknum untuk melakukan kecurangan dengan membuka segel yang mudah untuk dikembalikan sebagaimana kondisi semula. Di samping membuka segel dan mengambil soal kemudain dikerjakan, ada juga pola yang digunakan oleh pihak sekolah untuk mengerjakan soal unas ketika berlangsung, yaitu memanfaatkan soal cadangan yang jarang sekali diperhatikan keberadaanya. Ketika peserta didik mengerjakan soal unas, tim sukses sekolah juga mengerjakan di suatu ruang di sekolah tersebut. 30 menit sebelum jatah waktu habis, jawaban sudah terdistribusi secara merata ke seluruh siswa. ${ }^{17}$ Memang sulit membuktikan sebab tidak ada bukti bahkan pengawas dari perguruan tinggi juga tidak mengetahui adanya kecurangan ketika pelaksanaan unas berlangsung.

b) Membetulkan jawaban siswa pasca-UN

Pola kedua yang digunakan adalah membetulkan lembar jawaban peserta didik. Pola ini dilakukan ketika waktu pelaksanaan unas berakhir tiap harinya, lembar jawaban dibawa ke sebuah ruang khusus. Di sanalah tim sukses bekerja membenahi jawaban siswa yang salah. Pengawaas dan tim independen "dijamu" sedemikian rupa sehingga mereka tidak boleh mendekat ke ruang yang dipakai untuk melakukan

17 Hasil investigasi tim pengawas di sebuah SMAN di daerah tapal kuda. 
ketidakjujuran tersebut. Pola ini sudah banyak ditinggalkan karena mudah untuk dideteksi.

c) Usaha siswa sendiri

Di samping mengandalkan pemberian jawaban dari tim sukses sekolah, peserta didik sekarang ini lebih proaktif mencari "bocoran" jawaban unas. Tentunya bocoran ini tidak gratis. Mereka harus membayar sampai dengan 4 juta rupiah untuk mendapatkan jawaban keseluruhan mata pelajaran yang diunaskan. ${ }^{18}$ Untuk membayar harga tersebut biasanya ada "pengepul" tiap sekolah untuk membeli secara bersama-sama (patungan).

Menurut informasi yang penulis terima adalah jawaban tersebut sudah diterima oleh siswa 3 hari sebelum pelaksanaan berlangsung dan didistribusikan lewat sms. Penjelasan seorang siswa yang menjadi "pengepul" tersebut dikuatkan salah seorang guru yang merangkap guru di sebuah lembaga bantuan belajar. Hal yang cukup mengherankan adalah pihak kepolisian mengidentifikasi bawah jawaban yang diberikan via sms tersebut 99 benar, meskipun pihak koordinator UN di Jawa Timur, ITS, masih menyangsikan kebenaran jawaban tersebut sebab yang tahu jawaban persis tiap mata pelajaran adalah BNSP.

\footnotetext{
18 Hasil inverstigasi penulis kepada salah seorang siswa. Penjelasan siswa ini dibenarkan dan dikuatkan oleh seorang guru yang merangkap tutor di sebuah lembaga bantuan belajar yang mengetahui adanya pertemuan di sebuah hotel untuk mengerjakan soal-soal unas tersebut yang kemudian dijual dengan harga yang cukup tinggi.
} 


\section{E. Penutup}

Tujuan pelaksanaan UN sebagai bentuk evaluasi belajar merupakan upaya pemerintah untuk menstandarkan lulusan baik di level dasar maupun menengah. Upaya ini menimbulkan pro dan kontra tidak hanya di kalangan akademisi, birokrat bahkan di akar rumput sekalipun. Terlepas dari pro dan kontra, UN tetap dilaksanakan dan masih menyisakan permasalahan yang cukup krusial, yaitu masih adanya kecurangan atau ketidakjujuran dalam pelaksanaannya. Pakta integritas yang ditandatangani bahkan disumpahkan tinggallah pakta integritas ketika berhadapan dengan kepentingan yang dianggap lebih besar oleh para oknum, misalnya, taruhan jabatan di sebuah instansi atau sekolah, dan/atau sebuah prestise sekolah supaya tetap eksis sehingga apapun dilakukan termasuk academic dishonesty yang terkadang diatur lebih sistematis sehingga sulit untuk dideteksi keberadaannya.

\section{DAFTAR PUSTAKA}

A. Hope MA, Kebiasaan Nyontek adalah Musuh Perkembangan Anak (Jakarta: Rajawali, 1992).

B. Simandjuntak, Pengantar Kriminologi dan Patologi Sosial (Bandung: Tarsito, 1981)

Bushway and Nash, 1977, 623 dalam John R. Godfrey and Russell

F. Wough, "The Perception of Students from Religious Schools about Academic Dishonesty," Issues in Educational Research.

Concise Oxford Dictionary, Thompson, 1995.

Departemen Pendidikan dan Kebudayaan, Kamus Bahasa Indonesia (Jakarta: Balai Pustaka, 1996). 
Emil Salim, Mencari Strategi Pengembangan Pendidikan Nasional Menjelang Abad XXI (Jakarta: Grasindo, 1991).

Hadi Nur, "Eika Sains; Aspek penting dalam Riset dan Pendidikan Tinggi di Indonesia," di Internet dengan alamat http://www.angelfire.com/mt/hadinur/diskusi3.htm;Bac a juga Majalah GAMMA No. 06-2-04-04-2000.

Http://education.curtin.edu.au/iier8/godfrey.html

Hasil investigasi tim pengawas di sebuah SMAN di daerah tapal kuda.

Hasil inverstigasi penulis kepada salah seorang siswa.

Imam Haryanto, "Bahaya Menyontek di Kalangan Peserta didik," Pikiran Rakyat 18 Nopember 1985.

John R. Godfrey dan Russell F. Waugh, "The Perception of Student from Religious Schools about Academic Dishosnesty," dalam Issues in Educational Research, 8 (2), 1998.

James S. Cogelasi, Merancang Tes untuk Menilai Prestasi Peserta didik (Bandung: ITB, 1995).

UU No. 20 Tahun 2003 tentang Sistem Pendidikan nasional.

Wilbert J. McKeachie, Teaching Tips (Lexington: DC Heath Company, 1994). 